\title{
JUSTICE BRENNAN AND THE RELIGION CLAUSES: THE CONGEPT OF A "LIVING CONSTITUTION"
}

\section{ARLIN M. ADAMS $\dagger$}

In a speech addressing the use of history in constitutional interpretation, Justice William J. Brennan emphasized that the Constitution is a living document subject to "contemporary ratification" and that the judiciary must interpret the text to promote human dignity in light of society's changing values and needs. ${ }^{1}$ He stressed that it is this continual change in societal needs and relationships over time that often renders ineffective the pursuit for "the intention of the Framers" on contemporary issues, and he noted that ${ }^{~}[\mathrm{i}] \mathrm{t}$ is arrogant to pretend that from our vantage we can gauge accurately the intent of the Framers on application of principle to specific, contemporary questions. ${ }^{2}$

This view of the Constitution as a living and evolving document whose interpretation should not be cabined by too literal a quest for the Framers' intent ${ }^{3}$ is a position that Justice Brennan consistently defended and thoughtfully espoused in his opinions regarding the first amendment religion clauses. It constitutes one of the many contributions by this great jurist.

While Justice Brennan made many contributions to numerous facets of the law in his thirty-four year tenure on the Court, ${ }^{4}$ his opinions in the area of religion most prominently display his stance that the America of the founding fathers was different from the America of today and that the Bill of Rights must be read in a way that reflects this change. Specifically, Justice Brennan's decisions in

† Counsel to Schnader, Harrison, Segal \& Lewis, retired Judge of the United States Court of Appeals for the Third Circuit, who gratefully acknowledges the assistance of Lori S. Cozen, Esq., in the preparation of this Article.

${ }^{1}$ Speech by Justice Brennan at Georgetown University, The Constitution of the United States: Contemporary Ratification (Oct. 12, 1985), reprinted in A. MASON \& D. STEPHENSON, AMERICAN CONSTITUTIONAL LAW 607 (1987) [hereinafter Brennan]; see also A. ADAMS \& C. EMMERICH, A NATION DEDICATED TO RELIGIOUS LIBERTY: THE CONSTITUTIONAL HERITAGE OF THE RELIGION CLAUSES 36 (1990).

2 Brennan, supra note 1 , at 609 .

${ }^{3}$ See School Dist. of Abington Township v. Schempp, 374 U.S. 203, 237 (1963) (Brennan, J., concurring).

${ }^{4}$ Justice Minton retired from the United States Supreme Court on October 15, 1956, and Justice Brennan filled his vacant seat the next day. 
School District of Abington Township v. Schempp, ${ }^{5}$ Sherbert v. Vermer, ${ }^{6}$ Marsh v. Chambers, ${ }^{7}$ Lynch v. Donnelly, ${ }^{8}$ and County of Allegheny v. $A C L U^{9}$ are worthy of note because they evince his desire to preserve the autonomy and diversity of religious groups in Ameri$\mathrm{ca}^{10} \mathrm{a}$ desire which often was minimized by other members of the Court, but which Justice Brennan constantly sought to fulfill in his role as defender, as he saw it, of a "living Constitution."

The religion clauses of the first amendment preclude Congress from passing any law "respecting an establishment of religion, or prohibiting the free exercise thereof."11 It is in these provisions, referred to as the establishment and free exercise clauses, that constitutional concepts of religious autonomy were first articulated. The Court has extended the clauses' textual proscription of federal governmental conduct to state and local governments as well. ${ }^{12}$

In his opinions on the religion clauses, Justice Brennan frequently focused on whether the contemporary practice at issue conflicted with the fundamental meaning of the first amendment. ${ }^{13}$ While accepting historical evidence as an aid to answering contemporary questions, he admonished that the use of such evidence should be circumscribed. ${ }^{14}$ Brennan's opinions in the religion clause controversies reveal his respect for religious autonomy and, consequently, his concern that government not become impermissibly involved with religion.

Sherbert $v$. Verner, ${ }^{15}$ a case decided under the free exercise clause, demonstrates Brennan's position that government must not place a substantial burden on an individual's free exercise rights. ${ }^{16}$

5374 U.S. 203, 237 (1963) (Brennan, J., concurring).

6374 U.S. 398 (1963).

7463 U.S. 783, 795 (1983) (Brennan, J., dissenting).

8465 U.S. 668, 694 (1984) (Brennan, J., dissenting). part).

9109 S. Ct. 3086, 3124 (1989) (Brennan, J., concurring in part and dissenting in

10 See L. Tribe, American Constitutional LaW 1295-98 (1988).

$"$ U.S. CONST. amend. I.

12 See Cantwell v. Connecticut, 310 U.S. 296, 303 (1940) (holding that the free exercise of religion is embraced by the concept of liberty in the fourteenth amendment); see also Everson v. Board of Educ., 330 U.S. 1, 15 (1947) (holding that neither a state nor the federal government could set up a church or pass laws that aid religion or prefer one religion over another).

${ }^{13}$ See Ray, Justice Brennan and the Jurisprudence of Dissent, 61 TEMP. L. REV. 307, 331 (1988).

${ }^{14}$ See id. at 331.

15374 U.S. 398 (1963).

${ }^{16}$ See id. at 404. 
Sherbert concerned a member of the Seventh-Day Adventist Church who was discharged by her South Carolina employer because she would not work on Saturday, the sabbath day of her faith. Unable to obtain other employment because of her conscientious objection to Saturday work, Adell Sherbert filed a claim for unemployment compensation benefits under the South Carolina Unemployment Compensation Act. The Act provided that a claimant was ineligible for benefits if she failed, without cause, to accept suitable work that had been offered. The Unemployment Commission denied her claim on the ground that she would not accept suitable work, but the Supreme Court, in an opinion by Justice Brennan, held that the denial of benefits abridged Sherbert's constitutional right to the free exercise of her religion. ${ }^{17}$

Speaking for the Court, Justice Brennan addressed primarily two questions in reaching his conclusion. First, he considered whether Sherbert's disqualification as a beneficiary represented an infringement by the state on her free exercise rights. Second, he examined whether some compelling state interest justified the substantial infringement of the employee's first amendment rights. ${ }^{18}$ Justice Brennan concluded that the statute imposed a burden on Sherbert's free exercise rights because it forced her to choose between following the tenets of her religion and forfeiting benefits, on the one hand, or abandoning one of the precepts of her religion in order to work, on the other hand. ${ }^{19}$ Further, he determined there was no "compelling state interest" present in the statute's eligibility provisions that justified an infringement of Sherbert's constitutional right to religious freedom, ${ }^{20}$ and he noted that the state did not demonstrate that there could be no "less restrictive" way of preventing fraudulent claims by persons feigning religious objections to Saturday work as a pretext for laziness. ${ }^{21}$

The Sherbert opinion sets forth the proposition that an individual's right to religious freedom should not be delimited by government, unless government has a compelling reason for such an abridgement and demonstrates that there is no "less restrictive"

17 See id. at 410 .

18 See id. at 403 .

19 See id. at 404 . But see Braunfeld v. Brown, 366 U.S. 599 (1961) (holding, contrary to Brennan's dissent, that the free exercise clause does not constitutionally require an exception from Sunday closing laws for those who on religious grounds observe a different day of rest).

${ }^{20}$ See Sherberh 374 U.S. at 406-07.

${ }^{21}$ See id. at 407. 
way of accomplishing the goal. Brennan perceptively observed that "[i]t is too late in the day to doubt that the libert[y] of religion ... may be infringed by the denial of or placing of conditions upon a benefit or privilege." 22 Justice Brennan's disinclination, in Sherbert, to allow any type of governmental imposition upon an individual's free exercise rights manifests his desire to preserve religious autonomy in America.

On the same day the Court announced its ruling in Sherbert, it handed down its decision in School District of Abington Township $v$. Schempp. ${ }^{23}$ Justice Brennan did not write for the majority in Schempp but instead filed a lengthy concurring opinion which provides "a comprehensive and illuminating survey" of the problems raised under the establishment clause of the first amendment. ${ }^{24}$

Schempp dealt with a Pennsylvania statute that required Bible reading in public schools but permitted the excusal of students upon their parents' request. The Court noted that '[t]hese exercises are prescribed as part of the curricular activities of students who are required by law to attend school," ${ }^{25}$ and it held such official mandate of religious activity and pressure on a captive audience rendered the provisions unconstitutional under the establishment clause. ${ }^{26}$ The Court also found that the excusal provision could not validate the exercises. ${ }^{27}$

Justice Brennan detailed at considerable length his reasons for joining the Court's judgment. In his discussion of the meaning of the first amendment, Brennan argued for placing less reliance than the majority would place on the historical approach to deciding establishment clause cases, pointing out that "an awareness of

${ }^{22}$ Id. at 404. Justice Brennan made this statement in recognition of the fact that the South Carolina court's construction of the statute could not be saved from constitutional infirmity on the basis that unemployment benefits were not the appellant's "right" but merely a "privilege." See id.

23374 U.S. 203 (1963).

24 See Kauper, Schempp and Sherbert: Studies in Neutrality and Accommodation, 1963 RELIGION \& PUB. ORD. 3, 6.

25 Schempp, 374 U.S. at 223.

26 See id.

${ }^{27}$ See id. at 224-25. The Court concluded that the program was unconstitutional in light of its earlier holding in Engel v. Vitale, 370 U.S. 421 (1962). See Schempp, 374 U.S. at 224-25. In that case, school principals were directed to require each class to read aloud a prayer, composed by the State Board of Regents, at the beginning of the school day. See Engel, 370 U.S. at 422. The Court noted that it was "no part of the business of government to compose official prayers for any group of the American people to recite," and therefore the school board's action in prescribing the daily recitation was an impermissible establishment of religion. See id. at 425. 
history and an appreciation of the aims of the founding fathers do not always resolve concrete problems. ${ }^{28} \mathrm{He}$ argued that recorded history frequently is ambiguous and that statements readily can be found to support conflicting interpretations of the establishment clause. ${ }^{29}$

Brennan also recognized in Schempp that American education has changed substantially since the first amendment was adopted, and thus "any views of the eighteenth century as to whether the exercises at bar are an 'establishment' offer little aid to decision. ${ }^{\text {30 }}$ He further observed that religion in America today is much more pluralistic than it was in the America of our forefathers because of the growing diversity in religious beliefs and practices in the latter part of the twentieth century. ${ }^{31}$ Consequently, he concluded that the Court's interpretation of the first amendment must be responsive to the much more provocative nature of religious questions in contemporary society, noting that " $[w]$ hatever Jefferson or Madison would have thought of Bible reading or the recital of the Lord's Prayer in what few public schools existed in their day, our use of the history of their time must limit itself to broad purposes, not specific practices." ${ }^{32}$ In Schempp, therefore, Justice Brennan made the "sensible, but not necessarily obvious" point that many of today's problems were not envisioned by the Framers, and thus "too literal [a] quest for the advice of the Founding Fathers ... [is often] futile."34

While Justice Brennan was frequently in the majority in cases construing the religion clauses in the sixties, in the eighties he often found himself dissenting. Marsh v. Chambers ${ }^{35}$ and Lynch $v$. Donnelly ${ }^{36}$ represent two illustrations of Justice Brennan's break with the majority in this critical area. In Marsh, Ernest Chambers, a member of the Nebraska legislature, brought suit challenging the legislature's practice of selecting and paying a chaplain to offer

${ }^{28}$ Schempp, 374 U.S. at 234 (Brennan, J., concurring); see also Comment, School Prayer and the Constitution: Silence is Golden, 48 MD. L. REV. 1018, 1024-25 \& n.36 (1989).

29 See Schempp, 374 U.S. at $237-38$ (Brennan, J., concurring).

${ }^{30} \mathrm{Id}$. at 238.

${ }^{31}$ See id. at 240.

32 Id. at 241.

33 Pollak, The Supreme Court 1962 Term, 77 HARv. L. REv. 62, 69 (1963).

${ }^{34}$ Schempp, 374 U.S. at 237 (Brennan, J., concurring).

${ }^{35} 463$ U.S. 783 (1983).

${ }^{36} 465$ U.S. 668 (1984). 
prayers at the beginning of each session. ${ }^{37}$ The Supreme Court upheld the Nebraska chaplaincy program, noting that for almost two hundred years the United States Congress has opened each session with a prayer and that the same practice has persisted in Nebraska and other states for more than a century. ${ }^{38}$ While the Court recognized that "[s]tanding alone, historical patterns cannot justify contemporary violations of constitutional guarantees, ${ }^{n 99}$ it found support for its holding in the fact that the same Congress that drafted and approved the first amendment also appointed and paid a congressional chaplain. The Court concluded, therefore, that it would be "incongruous to interpret [the establishment clause] as imposing more stringent First Amendment limits on the states" than Congress imposed on itself. ${ }^{40}$

In dissenting, Justice Brennan began his exegesis by admitting that although he had expressed a position similar to that of the majority in his concurring opinion in Schempp, he now realized that such a position-one of tolerance for legislative prayer ${ }^{41}$-was

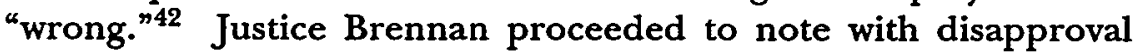
the majority's use of history to resolve conclusively the issue of legislative prayers. ${ }^{43} \mathrm{He}$ asserted that the majority was "misguid-

${ }^{37}$ See Marsh, 463 U.S. at 785.

${ }^{38}$ See id. at 788-89.

${ }^{39}$ Id. at 790 .

${ }^{40} \mathrm{Id}$. at $790-91$.

${ }^{41}$ In Schempp, Justice Brennan had stated:

The saying of invocational prayers in legislative chambers, state or federal, and the appointment of legislative chaplains, might well represent no involvements of the kind prohibited by the Establishment Clause. Legislators, federal and state, are mature adults who may presumably absent themselves from such public and ceremonial exercises without incurring any penalty, direct or indirect.

School Dist. of Abington Township v. Schempp, 374 U.S. 203, 299-300 (1963) (Brennan, J., concurring) (footnote omitted).

42 See Marsh, 463 U.S. at 796 (Brennan, J., dissenting). Brennan's forthright acknowledgement that his position on legislative prayer was misguided in Schempp, brings to mind the perceptive words of Justice Frankfurter: "Wisdom too often never comes, and so one ought not to reject it merely because it comes late." Henslee v. Union Planters Nat'l Bank \& Trust Co., 335 U.S. 595, 600 (1949) (Frankfurter, J., dissenting).

43 See Marsh, 463 U.S. at 815-16 (Brennan, J., dissenting). At the time the Court

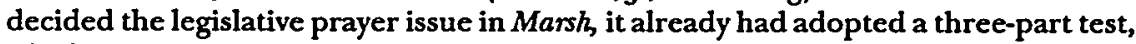
which was articulated in Lemon v. Kurtzman, 403 U.S. 602 (1971). Under the Lemon test, a law does not violate the establishment clause if it has a secular purpose, the primary effect of the law is not to advance or inhibit religion, and the law does not foster an excessive government entanglement with religion. See id. at 612-13. Justice Brennan contended that the Court should have applied the Lemon test to the facts in 
ed" when it relied on the fact that chaplains were employed by the first Congress at the time the Bill of Rights was drafted as the basis of its holding, explaining that "the Constitution is not a static document whose meaning on every detail is fixed for all time by the life experience of the Framers." 44 Furthermore, he pointed out that in interpreting cases under the establishment clause, the Court must recognize the important principle of religious freedom in a pluralistic society: "The Establishment Clause embodies a judgment, born of a long and turbulent history, that, in our society, religion 'must be a private matter for the individual, the family, and the institutions of private choice." $\$ 5$

In Lynch v. Donnelly, ${ }^{46}$ Justice Brennan was again at odds with the majority's interpretation of the establishment clause. The setting had changed from legislative prayer in Marsh to a government-sponsored nativity scene in Lynch. Still, Brennan found himself trying to persuade the Court to temper its reading of history with the recognition that American culture today is considerably different from what it was at the time of the Framers.

Lynch involved the city of Pawtucket, Rhode Island, which each year erected a Christmas display in a downtown shopping district. The display included, among other things, a Santa Claus house, a Christmas tree, candy-striped poles, and a life-sized nativity scene. ${ }^{47}$ Certain Pawtucket residents challenged the constitutionality of the presentation of the nativity scene, or "creche," in the annual display. The Supreme Court, reversing the court of appeals, held that the inclusion of the creche did not violate the establishment clause. ${ }^{48}$ Although the Court conceded that the creche had

Marsh instead of applying a purely historical analysis. Had the Court applied this test, stressed Brennan, "it would have [had] to strike [legislative prayer] down as a clear violation of the Establishment Clause." Marsh, 463 U.S. at 796 (Brennan, J., dissenting).

${ }^{44}$ Marsh, 463 U.S. at 816 (Brennan, J., dissenting). Brennan also pointed out that, concerning constitutional interpretation, Congress is not always as careful as the Supreme Court: "Legislators, influenced by the passions and exigencies of the moment, the pressure of constituents and colleagues, and the press of business, do not always pass sober constitutional judgment on every piece of legislation they enact, and this must be assumed to be as true of the Members of the First Congress as any other." Id. at 814-15 (footnote omitted).

${ }^{45} I d$. at 802 (quoting Lemon v. Kurtzman, 403 U.S. 602, 625 (1971)).

46465 U.S. 668 (1984).

47 The nativity scene consisted of the traditional figures, including the infant Jesus, Mary and Joseph, angels, shepherds, kings, and animals, all ranging in height from five inches to five feet. See id. at 671 .

${ }^{18}$ See id. at 687 . 
religious significance, it concluded that the city had a legitimate secular purpose in displaying it. It stated that the creche should be viewed in the context of the Christmas holiday season and, as such, its secular purpose became apparent in that the creche "depicts the historical origins of this traditional event long recognized as a National Holiday. ${ }^{49}$ The majority also declared that the creche did not advance religion any more than did lending textbooks to parochial school students or granting tax deductions to religious groups; these activities had already been held valid under the establishment clause. ${ }^{50}$ Finally, considering the question of entanglement, the Court held that the presence of political divisiveness was not sufficient to invalidate otherwise permissible conduct. $^{51}$

Justice Brennan sharply criticized the Court's holding, stating that nothing in the history of Christmas celebrations or the setting in which the city's creche was presented "obscures or diminishes the plain fact that Pawtucket's action amounts to an impermissible governmental endorsement of a particular faith. ${ }^{52}$ He pointed out that the nativity scene was central to the Christian faith, and, therefore, it was clearly distinct in its purpose and effect from the rest of the Christmas display because it was the only part of the display rooted in a biblical account of Christ's birth. ${ }^{53}$ Justice Brennan further argued that there was no support for the majority's

${ }^{49} I d$. at 680 . The Court appeared to analyze Pawtucket's action under the Lemon test. Justice Brennan, however, pointed out in his dissent that the Court was applying a less than rigorous application of the Lemon test. See id. at 696 (Brennan, J., dissenting). For a discussion of the three-part Lemon test, see supra note 43.

${ }^{50}$ See Lynch, 465 U.S. at 681-82.

${ }^{51}$ See id. at 683-85.

52 Id. at 695 (Brennan, J., dissenting). Brennan stated that Pawtucket's actions clearly violated the Lemon test and that the majority's loose interpretation of the test suggested that the majority's commitment to separatism may only be superficial. See id. at 697-98; see also Leading Cases of the 1983 Term, 98 HARV. L. REV. 87, 177 (1984) (noting Brennan's criticism of the majority's religious endorsement and its narrow application of the Lemon test).

${ }^{53}$ See Lynch, 465 U.S. at 708 (Brennan, J., dissenting). Brennan noted that the nativity scene "is the chief symbol of the characteristically Christian belief that a divine Savior was brought into the world and that the purpose of this miraculous birth was to illuminate a path toward salvation and redemption." Id. (footnote omitted). Accordingly, Brennan concluded that "[w]hen government appears to sponsor such religiously inspired views, we cannot say that the practice is "so separate and so indisputedly marked off from the religious function" . . that [it] may fairly be viewed as reflect[ing] a neutral posture toward religious institutions." Id. at 70809 (quoting Comm. for Pub. Educ. v. Nyquist, 413 U.S. 756, 782 (1973) (quoting Everson v. Bd. of Educ., 330 U.S. 1, 18 (1946))). 
use of historical evidence as proof that nativity scenes in governmental celebrations of Christmas have been accepted through time and thus did not violate the establishment clause. ${ }^{54}$ Rather, Brennan observed that at the time of adoption of the Constitution, and well into the nineteenth century, there was "no settled pattern of celebrating Christmas, either as a purely religious holiday or as a public event." ${ }^{\text {55 }}$

Although Justice Brennan recognized that an awareness of historical practice can provide a useful guide in interpreting the establishment clause, he cautioned that the use of such evidence is appropriate only when the evidence refers specifically to the challenged practice. ${ }^{56}$ Under the facts in Lynch, however, American historical experience concerning the celebration of Christmas does not support the validation of a government-sponsored nativity scene. Instead, he stressed, history reveals that the Framers of the establishment clause understood that "religion is too personal, too sacred, too holy to permit its "unhallowed perversion" by civil [authorities]."57 Finally, Justice Brennan concluded that instead of recognizing government's proper role with respect to religion, the majority reminded us that religious insensitivity still exists. ${ }^{58}$

A reading of Justice Brennan's dissenting opinions in Marsh and Lynch reveals his commitment to protect religious pluralism in America. He recognized that in determining the constitutionality of contemporary practices under the establishment clause, the Court must not look solely to the historical background of the first amendment, but instead it must recognize the importance of America's increasing religious diversity. Commenting on the challenge the Court faces in establishment clause cases, Justice Brennan noted in Marsh that "[o]ur primary task must be to translate 'the majestic generalities of the Bill of Rights, conceived as part of the pattern of liberal government in the eighteenth century, into concrete restraints on officials dealing with problems of the Twentieth Century." ${ }^{\text {59 }}$

54 See id. at 718.

55 Id. at 720.

56 See id. at 718-19, 725.

${ }^{57}$ Id. at 725 (quoting Engel v. Vitale, 370 U.S. 421, 432 (1962)).

${ }^{58}$ See id. at 725-26; Alstyne, Trends in the Supreme Court: Mr. Jefferson's Crumbling Wall-A Comment on Lynch v. Donnelly, 1984 DUKE L.J. 770, 787.

${ }^{59}$ Marsh v. Chambers, 463 U.S. 783, 816-17 (1983) (Brennan, J., dissenting) (quoting West Virginia Bd. of Educ. v. Barnette, 319 U.S. 624, 639 (1943)). 
More recently, in County of Allegheny $v . A C L U,{ }^{60}$ Justice Brennan declared that the Court's establishment clause analysis disclosed its continuing misunderstanding of "pluralism" in present-day society. ${ }^{61}$ In Allegheny, the Supreme Court addressed once again the issue that it had confronted in Lynch-whether governmental displays of religious symbols violate the concept of separation of church and state under the first amendment.

Allegheny dealt with the constitutionality of two religious displays located on governmental property in Pittsburgh. The first involved a creche placed on the "Grand Staircase" of the Allegheny County Courthouse; this nativity scene included figures representing Jesus, Mary, Joseph, shepherds, the wise men, farm animals, and an angel holding a banner declaring "Gloria in Excelsis Deo," meaning "Glory to God in the Highest." 62 The second display consisted of a forty-five foot Christmas tree next to an eighteen-foot menorah on the steps leading to the main entrance of the city-county building, located a block away from the courthouse. ${ }^{63}$ This display also included, at the bottom of the tree, a sign proclaiming Pittsburgh's devotion to liberty and to the legacy of freedom during the holiday season.

The Greater Pittsburgh Chapter of the American Civil Liberties Union and seven local residents alleged that each display violated the establishment clause, and the group sought a permanent injunction against display of both the creche and the menorah. ${ }^{64}$ A divided Supreme Court, speaking through Justice Blackmun, held that the presence of the creche demonstrated that the county took a position on the question of religion, amounting to an unconstitutional endorsement of the Christian faith. ${ }^{65}$ The Court further

60109 S. Ct. 3086 (1989).

61 See id. at 3129 (Brennan, J., concurring in part and dissenting in part).

62 See id. at 3093-94 \& n.5. The creche had been displayed on the Grand Staircase each year since 1981 by the Holy Name Society, a Roman Catholic group. There was a sign stating that the display was donated by the Holy Name Society. The creche was the setting for the county's annual Christmas carol program. See id. at 3093-94.

${ }^{63}$ See id. at 3097 . The menorah in Allegheny was owned by a Jewish group called Chabad, but it was erected and removed each year by the city. See id. "Menorah" is the Hebrew word for candelabrum, and the lighting of the menorah commemorates the Jewish observance of Chanukah. See id. at 3095-97 \& n.11.

64 See id. at 3097-98. The district court, relying on Lynch, held that neither display conveyed a message of governmental endorsement of religion. See id. at 3090 . The Court of Appeals for the Third Circuit reversed the district court decision, holding that the displays were governmental endorsements of the faiths they represented and, therefore, were unconstitutional. See ACLU v. County of Allegheny, 842 F.2d 655, 663 (3d Cir. 1988), aff'd in part and rev'd in part 109 S. Ct. 3086 (1989).

${ }^{65}$ See Allegheny, 109 S. Ct. at 3115 . The Court, discussing Lynch, noted that the 
held that because the menorah was situated near both a Christmas tree, a secular symbol of the holiday season, and a sign saluting liberty, it was not indicative of a government preference for any particular religion and not violative of the establishment clause. ${ }^{66}$ Instead, the Court concluded that, taken in its entirety, the menorah display was Pittsburgh's secular acknowledgement of cultural diversity in celebration of the "winter-holiday season. ${ }^{867}$

Justice Brennan concurred in the Court's judgment holding the display of the creche unconstitutional but dissented from the decision that upheld the display of the menorah. ${ }^{68}$ He criticized the Court's judgment relating to the menorah as resting on unsound logic. ${ }^{69}$ First, rejecting the Court's assertion that the Christmas tree is essentially a secular symbol, Brennan stated that the Court's "attempt to take the 'Christmas' out of the Christmas tree is unconvincing. ${ }^{\text {70 }}$ Even if a Christmas tree could be viewed as a secular symbol, reasoned Brennan, such a characterization would not be appropriate when the tree is displayed next to "such a forthrightly religious symbol" as the menorah. ${ }^{71}$ Thus, Justice Brennan concluded that the effect of the display was not a diminution of the religious character of the menorah, as the Court found, but rather an enhancement of the religious nature of the Christmas tree. ${ }^{72}$

location of the creche in a privately owned park and the presence of secular figures and decorations distinguished the Lynch display from the Allegheny County's creche, which stood alone in a government building. The Court maintained that because the creche was not surrounded by a larger secular display, nothing diminished its purely religious message. See id. at 3103-04.

${ }^{66}$ See id. at 3095,3116 . Specifically, Justice Blackmun determined that the menorah, although a religious object, acquired secular meaning by being placed next to a secular object, the Christmas tree, which transferred secular meaning to the menorah. See id. at 3113-14. Justice Blackmun concluded, therefore, that the objects from both religions, as well as the sign saluting liberty, made it unlikely that an average viewer of the display would see it as an endorsement of religion. See id. at 3115.

${ }^{67} \mathrm{Id}$. at 3114.

${ }^{68}$ See id. at 3124 (Brennan, J., concurring in part and dissenting in part).

${ }^{69}$ See id. at 3125 .

$70 \mathrm{Id}$.

71 Id. at 3126.

72 See id. at 3126-27; Comment, County of Allegheny v. ACLU: Evolution of Chaos in Establishment Clause Analysis, 40 AM. U.L. REV. 503, 530-31 (1990). Justice Brennan determined that the menorah's clear religious message would dominate the vague message presented by the Christmas tree. See Allegheny, 109 S. Ct. at 3127 (Brennan, $\mathrm{J}$, concurring in part and dissenting in part). 
Second, Justice Brennan sharply criticized the Court's finding that Chanukah is a holiday with secular dimensions, symbolized by the menorah. He stated that he could not "accept the effort to transform an emblem of religious faith into the innocuous 'symbol for a holiday that ... has both religious and secular dimensions." 73 Finally, Justice Brennan dismissed the Court's contention that the display of the menorah, the Christmas tree, and the sign advanced pluralism. ${ }^{74}$ In this respect, Brennan argued that even if the menorah display promotes a "pluralism" of beliefs, the display is still unconstitutional, since the establishment clause requires neutrality, not just among religions, but between religion and nonreligion. ${ }^{75}$ Justice Brennan concluded by pointing out that the Court's decision rested on the unsound premise that the government may promote pluralism by sponsoring or condoning displays having strong religious associations on its property. ${ }^{76} \mathrm{He}$ added: "This is not 'pluralism' as I understand it." ${ }^{\text {"77 }}$

In Allegheny, as in Marsi and Lynch, Justice Brennan concluded that once again the Court had failed to meet its obligation under the establishment clause to respect and defend our religious diversity as a nation. To him, the Court's holding in Allegheny that the menorah display was constitutional revealed simply that the Court was still not up to the challenge of interpreting the establishment clause in light of society's changing values and needs. ${ }^{78}$

What, then, is Justice Brennan's lesson in interpreting the religion clauses? Rejection of historical perspective in this area would be an overstatement of his view, just as focusing solely upon contemporary values would be too myopic. Rather, what Justice Brennan has provided, as seen through his interpretations of the religion clauses, is a grand scheme or majestic perception of the Constitution. His stance is one in which sensitivity replaces dogmatic rules, and a view in which continuum resides; one which honors original intent and, yet, adapts it to contemporary issues;

73 Allegheny, 109 S. Ct. at 3128 (Brennan, J., concurring in part and dissenting in part) (quoting the majority opinion).

71 See id.

${ }^{75}$ See id. Justice Brennan explained that he knew of "no principle under the Establishment Clause ... that permits us to conclude that governmental promotion of religion is acceptable so long as one religion is not favored." Id.

${ }^{76}$ See id. at 3125, 3128-29.

77 Id. at $\mathbf{8 1 2 9 .}$

${ }^{78}$ See Brennan, supra note 1, at 609 (advocating dynamic constitutional interpretation which encompasses social progress and changing social circumstances). 
one which permits the judicial interpreter to breathe deeply and see broadly. As he stated:

But the ultimate question must be, what do the works of the text mean in our time. For the genius of the Constitution rests not in any static meaning it might have had in a world that is dead and gone, but in the adaptability of its great principles to cope with current problems and current needs. ${ }^{79}$

Such is the heritage of Justice Brennan in one of the most important and most hallowed of the Constitution's protections.

${ }^{79}$ Id. at 610 . 
